\title{
Knowledge, Attitude and Practice regarding voluntary blood donation among the bachelor level students of Chitwan, Nepal \\ Pokhrel B*1, Pandey N ${ }^{2}$, Parajuli-Pokhrel K ${ }^{3}$ \\ School of Public Health and Department of Community Medicine \\ Chitwan Medical College, Bharatpur, Nepal
}

${ }^{1}$ Assistant Prof. , Community Medicine, Janaki Medical College, Janakpurdham, Nepal

${ }^{2}$ School of Public Health and Community Medicine, Chitwan Medical College, Bharatpur, Nepal

${ }^{3} \mathrm{MA}$, Food and Nutrition, Padma Kanya Multiple Campus, Kathmandu, Nepal

\begin{abstract}
Background and Objectives: Blood transfusion is a core service within health care systems and individuals who donate their blood in the treatment of sick human for different conditions such as surgery, accident, delivery and treatment of different diseases. The donation of blood by voluntary non-remunerated blood donors is recognized as being crucial for the safety and sustainability of national blood supplies. The study is carried out to find out the prevalence of blood donors and to explore the knowledge, attitude and practice on voluntary blood donation of medical students.
\end{abstract}

Material and Methods: Data were collected from a semi-structured questionnaire and technique was self-administered questionnaire to know the level of knowledge, attitude and practices of blood donation and analyze by using SPSS software among 167 medical students of Shree Medical and Technical College, Chitwan. The scoring system in knowledge was included. Attitude was assessed by using 3-point Likert scale.

Results: Majority of respondents (92.8\%) had heard about voluntary blood donation and almost all $(97.2 \%)$ respondents knew the correct meaning of voluntary blood donation. About 38.9\% had poor knowledge regarding voluntary blood donation and $61.1 \%$ of the respondents had good knowledge on voluntary blood donation and mean knowledge was found to be $56.17 \%$. Those respondents who had work experience had significantly low level of knowledge than who did not have work experience $(\mathrm{p}=0.0025)$.

Conclusion: To increase the prevalence of voluntary blood donation, specific campaigns involving interactive awareness sessions on blood donation should be organized, targeting the youth, motivating them to become regular voluntary blood donors should be conducted. Efforts must be undertaken to bring the knowledge and positive attitude towards students into application in future to achieve the goal of $100 \%$ VBD.

Key Words: Knowledge, Attitude and Practices, Voluntary blood donation

\section{INTRODUCTION}

Blood is vitally important for all living organism. Its importance is more felt in the treatment of sick human for different conditions such as surgery, accident, delivery cases and treatment of different diseases. Till now there is no substitute for blood and 
artificial blood is still in research laboratories. Blood transfusion is increasingly in use in medical science as it plays life-saving role in the treatment of thousands of patient daily.

Safe blood is blood that does not contain any viruses, parasites, drugs, alcohol, chemical substances, or other extraneous factors that might cause harm, danger or disease to the recipient. People who donate blood should be in good health and should not suffer or have suffered from any serious illnesses. The recipient should not be harmed by receiving blood; the donor should not be put at risk by giving blood. [1]

Blood transfusion is a core service within health care systems and individuals who donate their blood provide a unique contribution to the health and survival of others. Every country faces an ongoing challenge to collect sufficient blood from safe donors to meet national requirements. The donation of blood by voluntary nonremunerated blood donors is recognized as being crucial for the safety and sustainability of national blood supplies. [2]

The studies on voluntary blood donation are inadequate in Chitwan and in entire country. This study will explore present situation of knowledge, attitude and practice on voluntary blood donation of bachelor level students.

Eligibility for blood donation - Nepal Red Cross Society. [3]

Age: $18-60$ years of both male and female can donate blood.

Weight: More than $45 \mathrm{~kg}$ can donate blood.

Hemoglobin: $\geq 12 \mathrm{~g} /$ dl can donate blood.
Blood pressure: 100/70 - 160/95 mm Hg can donate blood.

Person suffering from epilepsy, tuberculosis, diabetes, hypertension, and HIV/AIDS infected person should not donate blood. Menstrual woman, lactating mother and pregnant women should donate. Unsafe sex and multi sex partner having people should not donate blood. Substance and drug abused people should not donate blood.

\section{MATERIAL AND METHODS}

\section{Study Area}

The study was conducted in Shree Medical and Technical College, Bharatpur, Chitwan District.

\section{Study Design}

The study design was Descriptive cross sectional study.

\section{Study Population}

Study population was bachelor level students of Shree Medical and Technical College, Chitwan.

\section{Sample Size (no)}

$$
\begin{gathered}
\mathrm{N}_{\mathrm{o}}=\frac{\mathrm{Z}^{2} \times \mathrm{P} \times \mathrm{Q}}{\mathrm{d} 2} \\
\mathrm{n}=\frac{\frac{1+\mathrm{n}_{\mathrm{o}}}{\mathrm{n}}}{\mathrm{N}}
\end{gathered}
$$

Where,

$\mathrm{n}=$ required sample size.

$\mathrm{z}=1.96$ for $95 \%$ confidence level.

$\mathrm{p}=$ proportion of KAP of students to be

0.18

$\mathrm{d}=$ precision or error allowed in the study $=0.05$.

$q=(1-p)$. 
$\mathrm{N}=$ total bachelor students enrolled in Shree Medical and Technical College.

$$
=\underline{(1.96)^{2} \times 0.19 \times 0.81}
$$

$$
\begin{aligned}
& (0.05) 2 \\
& =152+10 \% \text { of } 152 \\
& =167 \\
& =\frac{1+\frac{236}{236}}{431}
\end{aligned}
$$

Therefore, the total numbers of sample were 167.

Total no. of students by faculty:

$$
\begin{aligned}
& \text { B.N }=96 \\
& \text { BSc. Nursing }=66 \\
& \text { B. } \text { Pharmacy = } 134 \\
& \text { BPH }=135
\end{aligned}
$$

Sample from each faculty:

For B.N

$$
=167 \times 96 / 431
$$$$
=36
$$

For B. Pharmacy

$$
=167 \times 134 / 431
$$$$
=51
$$

For BSc. Nursing

$=167 \times 66 / 431$

$=27$

For BPH

$=167 \times 135 / 431$

$=53$

\section{Sampling Technique}

Shree Medical and Technical College was chosen purposively. Number of the participants was chosen proportionally through college attendance register using stratified simple random sampling.

\section{Inclusion Criteria}

Students who study in bachelor level will be included in the study.

\section{Exclusion Criteria}

Those who do not give informed consent.

\section{RESULTS}

\begin{tabular}{|c|c|c|}
\hline Characteristics & Frequency & Percent \\
\hline \multicolumn{3}{|l|}{$\begin{array}{l}\text { Interval of blood } \\
\text { donation }\end{array}$} \\
\hline Every month & 1 & 0.6 \\
\hline $\begin{array}{l}\text { Every 3-4 } \\
\text { months }\end{array}$ & 107 & 64.1 \\
\hline $\begin{array}{l}\text { Every } 6 \\
\text { months }\end{array}$ & 57 & 34.1 \\
\hline Every year & 2 & 1.2 \\
\hline \multicolumn{3}{|l|}{$\begin{array}{l}\text { Minimum weight for } \\
\text { blood donation }\end{array}$} \\
\hline $40 \mathrm{~kg}$ & 25 & 15 \\
\hline $45 \mathrm{~kg}$ & 72 & 43.1 \\
\hline $50 \mathrm{~kg}$ & 53 & 31.7 \\
\hline $55 \mathrm{~kg}$ & 17 & 10.2 \\
\hline \multicolumn{3}{|l|}{$\begin{array}{l}\text { Minimum age for } \\
\text { blood donation }\end{array}$} \\
\hline 16 year of age & 11 & 6.6 \\
\hline 18 year of age & 94 & 56.3 \\
\hline 20 year of age & 60 & 39.9 \\
\hline 22 year of age & 2 & 1.2 \\
\hline \multicolumn{3}{|l|}{$\begin{array}{l}\text { Minimum Hb level for } \\
\text { blood donation }\end{array}$} \\
\hline $10 \mathrm{~g} / \mathrm{dl}$ & 15 & 8.9 \\
\hline $11 \mathrm{~g} / \mathrm{dl}$ & 40 & 23.8 \\
\hline $12 \mathrm{~g} / \mathrm{dl}$ & 88 & 52.7 \\
\hline $13 \mathrm{~g} / \mathrm{dl}$ & 24 & 14.6 \\
\hline \multicolumn{3}{|l|}{$\begin{array}{l}\text { Quantity of blood } \\
\text { removed }\end{array}$} \\
\hline $150-250 \mathrm{ml}$ & 66 & 3.6 \\
\hline $250-350 \mathrm{ml}$ & 77 & 46.1 \\
\hline $350-450 \mathrm{ml}$ & 62 & 37.1 \\
\hline $450-500 \mathrm{ml}$ & 22 & 13.2 \\
\hline
\end{tabular}

Out of 167 respondents, majority number of students 82 (49.1\%) were below or equal to 23 years of age group, 102 (61.1\%) were female and 65 (38.9\%) were male.

About 53 (31.7\%) student were from Bachelor in Public Health, Bachelor in Nursing and B.Sc. Nursing 51 (30.5\%), 36 (21.6\%) and 27 (16.2\%).

Table 1. Distribution of Knowledge on Criteria of Voluntary Blood Donation ( $n=167)$

Table 1. Most of the respondents told that, time interval of blood donation is at 3 to 4 months of interval. $43.1 \%$ of the respondents said the minimum weight for blood donation 
should be $45 \mathrm{~kg}$. Whereas the minimum age for blood donation is 18 years of age $(56.3 \%)$.

Regarding hemoglobin level for blood donation, only $52.7 \%$ of the respondents knew correct hemoglobin level (12 g/ dl) for donate blood. Just $46.1 \%$ said $250 \mathrm{ml}-350 \mathrm{ml}$ blood is removed during blood donation where as $37.1 \%$ said $350 \mathrm{ml}-450 \mathrm{ml}$ blood is removed in blood donation.

Table 2. Distribution of knowledge of suffering from different problems during voluntary blood donation $(n=167)$

\begin{tabular}{|c|c|c|}
\hline Characteristics & Frequency & Percent \\
\hline \multicolumn{3}{|l|}{ Suffering from HIV / AIDS } \\
\hline Yes & 119 & 71.3 \\
\hline No & 41 & 24.6 \\
\hline Don't know & 7 & 74.2 \\
\hline \multicolumn{3}{|l|}{$\begin{array}{l}\text { Suffering from infectious } \\
\text { disease }\end{array}$} \\
\hline Yes & 114 & 68.3 \\
\hline No & 37 & 22.2 \\
\hline Don't know & 16 & 9.6 \\
\hline \multicolumn{3}{|l|}{$\begin{array}{l}\text { Suffering from bleeding } \\
\text { disorder }\end{array}$} \\
\hline Yes & 61 & 36.5 \\
\hline No & 57 & 34.1 \\
\hline Don't know & 49 & 29.3 \\
\hline \multicolumn{3}{|l|}{ Suffering from anemia } \\
\hline Yes & 103 & 61.7 \\
\hline No & 32 & 19.2 \\
\hline Don't know & 32 & 19.2 \\
\hline \multicolumn{3}{|l|}{$\begin{array}{l}\text { Suffering from mental } \\
\text { disturbances }\end{array}$} \\
\hline Yes & 48 & 28.9 \\
\hline No & 112 & 67.1 \\
\hline Don't know & 7 & 4.2 \\
\hline
\end{tabular}

Table 2 showed that $71.3 \%$ said there is risk of suffering from HIV / ADIS during blood donation while one quarter (24.6\%) said HIV / AIDS is not contracted during blood donation. Regarding infectious disease, $68.3 \%$ of the respondents said there is risk to a donor of suffer from infectious disease. Almost $36.5 \%$ respondents said there is likelihood of suffering from bleeding disorder while almost similar (34.1\%) respondents said there is no risk of suffering from bleeding disorder. Considering anemia,
$61.7 \%$ said there is risk of suffering from anemia but $19.2 \%$ said there is no risk of suffering from anemia. Likewise, $28.9 \%$ said risk of mental disturbance but $67.1 \%$ of the respondents said there is no risk of mental disturbance.

Out of 167 respondents, $81.4 \%$ of the respondents agree to the statement that they intend to donate blood within 6 months. All respondents $(100 \%)$ agreed to if they donate blood they will be saving lives. Only $10.8 \%$ agreed to the statement if they donate blood they will feel pain whereas $61.7 \%$ disagreed to the statement. Majority (90.4\%) of the respondents disagreed to the statement if they would be more likely to donate blood, if they were paid to do so.

Almost one fifth (18.6\%) agreed to the statement only physically strong people can donate blood but $54.5 \%$ disagreed to the same statement. Only $15 \%$ of the respondents agreed with the statement that blood should be collected by voluntarily but almost half of the respondents (49.1\%) disagreed the same statement. Nearly one fourth $(24.6 \%)$ of the respondents agreed to statement, blood donation is extremely safe and $34.7 \%$ disagreed to the statement while $40.7 \%$ were neutral. 93.4\% of the respondent agreed to someday I need blood transfusion. 55.7\% agreed to blood donation helps in blood purification while $9.6 \%$ disagreed and $34.7 \%$ were neutral to the same statement as shown in table 3. 38.9\% respondents had poor knowledge regarding voluntary blood donation and $61.1 \%$ of the respondents had good knowledge and mean knowledge $56.17 \%$ with standard deviation 11.39 as shown in table 4.

Table 3. Distribution of Attitude on Voluntary Blood Donation ( $n=167)$ 


\begin{tabular}{|c|c|c|}
\hline Characteristics & Frequency & Percent \\
\hline \multicolumn{3}{|l|}{$\begin{array}{l}\text { Intend to donate blood } \\
\text { within } 6 \text { months }\end{array}$} \\
\hline Agree & 136 & 81.4 \\
\hline Neutral & 27 & 16.2 \\
\hline Disagree & 4 & 2.4 \\
\hline \multicolumn{3}{|l|}{ Donating blood is noble act } \\
\hline Agree & 145 & 86.8 \\
\hline Neutral & 15 & 9 \\
\hline Disagree & 7 & 4.2 \\
\hline \multicolumn{3}{|l|}{$\begin{array}{l}\text { If I donate blood, I will be } \\
\text { saving lives }\end{array}$} \\
\hline Agree & 167 & 100 \\
\hline Neutral & - & - \\
\hline Disagree & - & - \\
\hline \multicolumn{3}{|l|}{$\begin{array}{l}\text { If I donate blood, I will feel } \\
\text { pain }\end{array}$} \\
\hline Agree & 18 & 10.8 \\
\hline Neutral & 46 & 27.5 \\
\hline Disagree & 103 & 61.7 \\
\hline \multicolumn{3}{|l|}{$\begin{array}{l}\text { I would be more likely to } \\
\text { donate blood, if I were to } \\
\text { paid to do so }\end{array}$} \\
\hline Agree & 6 & 3.6 \\
\hline Neutral & 10 & 6 \\
\hline Disagree & 151 & 90.4 \\
\hline \multicolumn{3}{|l|}{$\begin{array}{l}\text { Only physically strong } \\
\text { people can donate blood }\end{array}$} \\
\hline Agree & 31 & 18.6 \\
\hline Neutral & 45 & 26.9 \\
\hline Disagree & 91 & 54.5 \\
\hline \multicolumn{3}{|l|}{$\begin{array}{l}\text { Blood should be collected } \\
\text { only from Voluntary Donors }\end{array}$} \\
\hline Agree & 25 & 15 \\
\hline Neutral & 60 & 35.9 \\
\hline Disagree & 82 & 49.1 \\
\hline \multicolumn{3}{|l|}{$\begin{array}{l}\text { Blood donation is extremely } \\
\text { safe }\end{array}$} \\
\hline Agree & 41 & 24.6 \\
\hline Neutral & 68 & 40.7 \\
\hline Disagree & 58 & 34.7 \\
\hline \multicolumn{3}{|l|}{$\begin{array}{l}\text { Someday I need blood } \\
\text { transfusion }\end{array}$} \\
\hline Agree & 156 & 93.4 \\
\hline Neutral & 11 & 6.6 \\
\hline Disagree & - & - \\
\hline \multicolumn{3}{|l|}{$\begin{array}{l}\text { Blood donation helps in } \\
\text { blood purification }\end{array}$} \\
\hline Agree & 93 & 55.7 \\
\hline Neutral & 58 & 34.7 \\
\hline Disagree & 16 & 9.6 \\
\hline
\end{tabular}

Table 4. Distribution of category of Knowledge of Voluntary Blood Donation ( $n=167)$

\begin{tabular}{|c|c|c|}
\hline Characteristics & Frequency & Percentage \\
\hline Poor & 65 & 38.9 \\
\hline Good & 102 & 61.1 \\
\hline \multicolumn{2}{|c|}{ Mean \% (SD) 56.17 (11.39) } \\
\hline
\end{tabular}

Table 5. Shows, out of the total 167 respondents, only $23.4 \%$ had donated blood before and just over than three quarters (76.65) had not donated blood yet. Most (56.4\%) of the respondents said feeling social responsibility and $38.5 \%$ said being in donor group (peer) as the reason to donate blood. Out of 39 donors, only 10.3\% experienced adverse effect while donating blood. Just over half $(51.3 \%)$ had donated blood once while $23.1 \%$ had donated twice before. $35.9 \%$ of donors were planning to be regular donor.

Only $23.1 \%$ of donors plan ahead of blood donation. Regarding reasons not to donate blood, $35.2 \%$ said due to fear of weakness and venous puncture whereas $32 \%$ said due to medically unfit to donate blood. About $97 \%$ of the respondents said they had not received blood transfusion yet. Only one third (34.1\%) of respondents were participated in organizing blood donation camp. Concerning on parent's involvement in blood donation, only $43.7 \%$ of the respondents' parents had donated blood. Table 6. Shows that those respondents who had work experience had significantly low level of knowledge than who did not have work experience $(\mathrm{p}=0.025)$.

There is association with faculties of the respondents as the level of knowledge among the nursing was significantly higher $(88.9 \%)$ followed by BPH $(66 \%)$ than others $(\mathrm{p}=$ 0.02).

Table 5. Distribution of Practice on Voluntary Blood Donation ( $n=167)$ 


\begin{tabular}{|c|c|c|}
\hline Characteristics & $\begin{array}{l}\text { Freque } \\
\text { ncy }\end{array}$ & $\begin{array}{l}\text { Percenta } \\
\text { ge }\end{array}$ \\
\hline $\begin{array}{l}\text { Blood donated before } \\
\text { Yes } \\
\text { No }\end{array}$ & $\begin{array}{l}39 \\
128\end{array}$ & $\begin{array}{l}23.4 \\
76.6\end{array}$ \\
\hline $\begin{array}{l}\text { Reasons to donate blood } \\
\text { Feeling social responsibility } \\
\text { As an experience } \\
\text { Being in a group of donor } \\
\text { (peer) }\end{array}$ & $\begin{array}{l}22 \\
2 \\
15\end{array}$ & $\begin{array}{l}56.4 \\
5.1 \\
38.5\end{array}$ \\
\hline $\begin{array}{l}\text { Adverse effect while } \\
\text { donating blood } \\
\text { Yes } \\
\text { No }\end{array}$ & $\begin{array}{l}4 \\
35\end{array}$ & $\begin{array}{l}10.3 \\
89.7\end{array}$ \\
\hline $\begin{array}{l}\text { Total frequency of blood } \\
\text { donation by donors } \\
\text { One time } \\
\text { Two times } \\
\text { Three times } \\
\text { Four or more times }\end{array}$ & $\begin{array}{l}20 \\
9 \\
5 \\
5\end{array}$ & $\begin{array}{l}51.3 \\
23.1 \\
12.8 \\
12.8\end{array}$ \\
\hline $\begin{array}{l}\text { Planning to be regular } \\
\text { donor } \\
\text { Yes } \\
\text { No }\end{array}$ & $\begin{array}{l}14 \\
25\end{array}$ & $\begin{array}{l}35.9 \\
64.1\end{array}$ \\
\hline $\begin{array}{l}\text { Plan ahead of blood } \\
\text { donation } \\
\text { Yes } \\
\text { No }\end{array}$ & $\begin{array}{l}9 \\
30\end{array}$ & $\begin{array}{l}23.1 \\
76.9\end{array}$ \\
\hline $\begin{array}{l}\text { Reasons not to donate } \\
\text { blood } \\
\text { Medically unfit to donate } \\
\text { Parent do not allow } \\
\text { Fear of weakness and } \\
\text { venous puncture } \\
\text { Do not like the idea for } \\
\text { removing blood } \\
\text { Lack of opportunity } \\
\text { Lack of time }\end{array}$ & $\begin{array}{l}41 \\
18 \\
45 \\
19 \\
4 \\
1\end{array}$ & $\begin{array}{l}32 \\
14.1 \\
35.2 \\
14.8 \\
\\
3.1 \\
0.8\end{array}$ \\
\hline $\begin{array}{l}\text { Ever received blood } \\
\text { Yes } \\
\text { No }\end{array}$ & $\begin{array}{l}5 \\
162\end{array}$ & $\begin{array}{l}3 \\
97\end{array}$ \\
\hline $\begin{array}{l}\text { Participation in } \\
\text { organizing a blood } \\
\text { donation camp } \\
\text { Yes } \\
\text { No }\end{array}$ & $\begin{array}{l}57 \\
110\end{array}$ & $\begin{array}{l}34.1 \\
65.9\end{array}$ \\
\hline $\begin{array}{l}\text { Parents have donated or } \\
\text { donating blood } \\
\text { Yes } \\
\text { No } \\
\text { Don't know }\end{array}$ & $\begin{array}{l}73 \\
42 \\
52\end{array}$ & $\begin{array}{l}43.7 \\
25.1 \\
31.1\end{array}$ \\
\hline
\end{tabular}

Table 6 : Socio-Demographic Characteristics Associated with Level of Knowledge of Blood Donation.

\begin{tabular}{|c|c|c|c|c|}
\hline \multirow[t]{2}{*}{ Characteristics } & \multicolumn{2}{|c|}{$\begin{array}{c}\text { Level of } \\
\text { Knowledge } \\
\text { n (\%) }\end{array}$} & \multirow[t]{2}{*}{$\begin{array}{l}\text { Chi- } \\
\text { square } \\
\text { value }\end{array}$} & \multirow[t]{2}{*}{$\begin{array}{c}\text { p- } \\
\text { value }\end{array}$} \\
\hline & Poor & Good & & \\
\hline \multicolumn{5}{|l|}{ Sex } \\
\hline Male & 29 & 36 & & \\
\hline Female & $(44.6)$ & $(55.4)$ & 1.451 & 0.228 \\
\hline & $\begin{array}{c}36 \\
(35.3)\end{array}$ & $\begin{array}{c}66 \\
(64.7)\end{array}$ & & \\
\hline \multicolumn{5}{|l|}{ Work } \\
\hline Experience & & & & \\
\hline Yes & $(48.6)$ & $37(51.4)$ & 4.998 & 0.025 \\
\hline No & $\begin{array}{c}30 \\
(31.6)\end{array}$ & 65 (68.4) & & \\
\hline \multicolumn{5}{|l|}{ Faculty } \\
\hline $\begin{array}{l}\text { Faculty } \\
\text { BPH }\end{array}$ & $\begin{array}{c}18 \\
(34)\end{array}$ & $\begin{array}{c}35 \\
(66)\end{array}$ & & \\
\hline \multirow[t]{2}{*}{ B. Pharma } & 27 & 24 & & \\
\hline & (52.9) & $(47.1)$ & 14.592 & 0.02 \\
\hline BSc Nursing & $\begin{array}{c}3 \\
(11.1)\end{array}$ & $\begin{array}{c}24 \\
(88.9)\end{array}$ & & \\
\hline $\mathrm{BN}$ & $\begin{array}{c}17 \\
(42.2)\end{array}$ & $\begin{array}{c}19 \\
(52.8)\end{array}$ & & \\
\hline \multicolumn{5}{|l|}{$\begin{array}{l}\text { Marital } \\
\text { status }\end{array}$} \\
\hline Married & $\begin{array}{c}18 \\
(48.6)\end{array}$ & $\begin{array}{c}19 \\
(51.4)\end{array}$ & 1.892 & 0.169 \\
\hline Unmarried & $\begin{array}{c}47 \\
(36.2)\end{array}$ & $\begin{array}{c}83 \\
(63.8)\end{array}$ & & \\
\hline Ethnicity & & & & \\
\hline Brahmin & $\begin{array}{c}22 \\
(32.4)\end{array}$ & $\begin{array}{c}46 \\
(67.6)\end{array}$ & & \\
\hline Chettri & $\begin{array}{c}19 \\
(38)\end{array}$ & 31 (62) & 4.478 & 0.345 \\
\hline Newar & $9(60)$ & $6(40)$ & & \\
\hline Magar & $\begin{array}{c}6 \\
(46.2)\end{array}$ & 7 (53.8) & & \\
\hline Others & $\begin{array}{c}9 \\
(42.9)\end{array}$ & $\begin{array}{c}12 \\
(57.1)\end{array}$ & & \\
\hline
\end{tabular}

There was no significant association found with other socio - demographic characteristics and level of knowledge as shown in table 6. 


\section{DISCUSSION}

Majority of the respondents were up to 23 years of age and the mean age of the respondents was 23.95 which shows similar finding of Ogunbona $\mathrm{OB}$ et al study done in Nigeria where the respondents mean was 22 years [4] and the current study also somehow supports the finding of research done in Nepal by Amatya $M$ in similar topic which showed mean age 21.16 years [5].

In this study there were $38.9 \%$ male respondents and $61.1 \%$ were female respondents which favors the findings of the research done in India where there were $37.3 \%$ male respondents and $62.7 \%$ female respondents [6] and the current research somehow backup the finding of Nepalese study where the male and female respondents were $41.2 \%$ and $58.8 \%$ respectively [7].

This study stated that, $92.8 \%$ respondents had heard about voluntary blood donation which is similar findings show that only $97.4 \%$ of the respondents knew the correct meaning of voluntary blood donation which is low in term of number as compared with a Jamaican study which showed $100 \%$ of the respondents knew the correct meaning of voluntary blood donation. [8]

This study showed, $71.3 \%$ of respondents are aware of risk of HIV / AIDS through blood transfusion and $68.3 \%$ are aware of contracting infectious disease via blood donation. A Rajkot study showed, 96\% respondents were aware of transmitting infectious diseases [9].

\section{CONCLUSION}

Being knowledgeable and having positive attitude regarding voluntary blood donation does not transform into actual practice of blood donation. Therefore, specific recruitment and motivational campaigns are needed targeting the younger adults. Our efforts should be towards bringing the knowledge, awareness and the positive attitude of the students into application by motivating them and creating opportunities for them to become regular voluntary blood donor.

\section{ACKNOWLEDGEMENT}

I am grateful to the faculties members and students of School of Public Health and Community Medicine, CMC, Bharatpur and all the participants of Shree Medical and Technical College, Bharatpur, Chitwan.

\section{REFERENCES}

1. WHO. Safe blood starts with me! Blood saves lives! Stories and souvenirs from World Health Day 2000 together with useful information on blood safety. Geneva: WHO; 2001 Dec. pp 12.

2. WHO. Towards $100 \%$ voluntary blood donation: a global framework for action. WHO Press Geneva: World Health Organization; 2010. pp 1.

3. Nepal Red Cross Society. Blood donation: general information. Kathmandu: Nepal Red Cross Society Central Blood Transfusion Service; 2014. pp 44.

4. Ogunbona OB et al. Knowledge and practice of blood donation among university undergraduates. Highland Med Res J 2013; 13(1): 26-30.

5. Amatya M, Gorkhali B, Mahotra N, Prajapati R, Yadav SR. Knowledge, attitude, and practice of medical students on blood donation: a comparison between two medical colleges of Nepal. Int J Curr Res 2013; 5(9):2641-2644.

6. Karakkamandapam S, Remya A, Binu VS, Raghavan V. Knowledge, attitude and practice on Blood Donation among Health Science Students in a University campus, South India. Online J Health and Allied Sci. 2011; 10 (2): 13.

7. Amatya M. Study on knowledge, attitude and practice of blood donation among students of different colleges of Kathmandu, Nepal. Int J Pharm \& Biol Archives 2013; 4(3): 424 - 428. 
8. Bourne PA, Richards S, Nevins DH. Knowledge, attitude, practices and readiness among University Science Students Toward NonRemunerated Blood Donation in a MiddleIncome Developing Country. TAF Preventive Med Bulletin 2013; 12(5):529-538.

9. Amit A et al. Knowledge, attitude, and practice of voluntary blood donation among medical students of PDU medical college, Rajkot. Int J Curr Res 2013; 5(6): 6839-6841.

Correspondence to:

Dr. Bishal Pokhrel

Department of Community Medicine, Janaki Medical College

Janakpurdham, Nepal

E-mail: dr.bishalpokhrel@gmail.com 